\title{
PERILAKU MEMBERI MAKAN UNTUK MENINGKATKAN TUMBUH KEMBANG ANAK
}

\author{
Yayah K. Husaini ${ }^{1}$ \\ 'Peneliti Utama pada Puslitbang Gizi dan Makanan, Badan Litbang Kes, Depkes RI, Bogor
}

\begin{abstract}
FEEDING BEHAVIOUR FOR BETTER GROWTH AND DEVELOPMENT

The widespread malnutrition in children especially among those under two years of age is closely linkage not only to poverty but also to inappropriate child caring practices particularly feeding behavior and infection. Complementary foods given into an infant's diet in addition to breast milk after the child above 6 months old either commercially or specially prepared at home are needed to meet the nutrient requirements. The Pengalengan study shows that children with better nutritional status because of local food supplements in early infancy perform better cognition in later life. Therefore, to empower women who are the main caregiver with knowledge and skill is necessary to optimal nutritional benefits for their children.
\end{abstract}

Key wood: Feeding behaviour, growth, development

\section{PENDAHULUAN}

K edaan gizi pada waktu bayi dan anak berperanan dalam meletakkan dasardasar kesehatan bayi dan anak pada waktu ini dan kelak pada waktu dewasanya. Keadaan kurang gizi pada bayi dan anak adalah akibat dari pemberian makanan yang tidak cukup memenuhi gizi dalam hal kualitas berkombinasi dengan seringnya anak menderita sakit terutama diare (1). Pada waktu ini kekurangan gizi merupakan masalah pokok dalam bidang kesehatan.

Akhir-akhir ini kita sering mendengar bahwa Gizi Buruk tersebar dimana-mana dalam jumlah relatif tinggi yaitu $5-10 \%$, dan angka tersebut merupakan salah satu tertinggi didunia. Gizi Buruk terdiri dari 3 kelompok yaitu marasmus, kwashiorkor dan marasmic-kwashiorkor.

Marasmus berasal dari bahasa Ghana yang berarti sisa. Sisa artinya tidak ada otot dan lapisan lemak di bawah kulit, kulit kering serta keriput, dan ukuran badan kecil kurang dari $60 \%$ berat badan normal. Mukanya mirip orang tua yang dalam bahasa Inggeris disebut old face. Kwashiorkor dari bahasa Ghana artinya anak kedua, dimana anak pertama menderita Gizi Buruk karena lahirnya anak yang ke dua yang jaraknya terlalu dekat. Tubuhnya bengkak terutama dibagian kaki dan muka sehingga disebut moon face, artinya muka bulat seperti bulan purnama. Kulitnya kasar, dematosis dan depigmentasi, kadang-kadang terlepas seperti kulit terbakar. Rambutnya jarang dan mudah tercabut. Perut membesar karena hepatomegali, tidak bertenaga, tidak dapat merangkak atau berjalan. Marasmikkwashiorkor adalah kondisi yang paling berat yang merupakan kombinasi antara marasmus dan kwashiorkor. Badannya kecil tetapi bengkak. Gejala-gejala yang terdapat pada marasmus dan kwashiorkor dijumpai pada anak ini. Anak yang menderita Gizi Buruk memmpunyai kesempatan meninggal dunia $50 \%$, atau dengan kata lain kemungkinan terus hidup atau meninggal dunia sama besarnya (1)(2).

Keadaan kekurangan gizi yang lebih ringan disebut Kurang Gizi yang jumlahnya jauh lebih banyak yaitu dengan prevalensi 25 - 30\%. Kurang Gizi menyebabkan pertumbuhan fisik terlambat, perkembangan kecerdasan rendah, dan kemampuan kerja fisik juga rendah. Untuk meningkatkan kualitas anak-anak kita, maka keadaan gizi 
harus ditingkatkan atau dicegah terjadinya Kurang Gizi (3).

Upaya agar anak tidak menderita Kurang Gizi apalagi Gizi Buruk, dilakukan melalui penyuluhan gizi dan kesehatan agar ibu-ibu tahu, mau dan mampu berperilaku lebih baik dalam mengasuh dan memberi makan anaknya. Memberi makan anak adalah suatu ilmu dan seni agar anak tumbuh tidak kurus (Kurang Gizi) atau sebaliknya terlalu gemuk karena kelebihan gizi.

\section{KURANG GIZI VERSUS KEGEMU- KAN}

Di masyarakat yang maju dan orangtuanya berkecukupan, ada kecendrungan bertambah banyak anak yang terlalu gemuk. Apabila sejak kecil anak sudah gemuk, maka besar kemungkinan setelah dewasa tetap gemuk. Sebaliknya di daerah dimana banyak kemiskinan, banyak anak yang kurang gizi yang badannya kurus dan mudah terkena infeksi. Kemungkinan meninggal anak-anak ini cukup tinggi, dan kalaupun dia masih selamat dan tetap hidup, akan dapat berakibat kurang cerdas, produktifitas dan kreatifitas rendah, serta kegairahan hidup menurun

Anak terlalu gemuk atau terlalu kurus, kedua-duanya adalah tidak baik. Menurut berbagai pengamatan, penyebab utama adalah penggunaan susu komersial (susu botol = susu yang diminum melalui botol) sebagai pengganti ASI. Pada masyarakat maju, bayi yang diberikan susu botol biasanya mendapat kalori yang lebih tinggi dari seharusnya. Hal ini disebabkan karena: (i) ibu selain memberi susu botol juga memberi makanan campuran yang lebih cepat dari seharusnya; dan (2) ibu sering menyiapkan susu botol lebih pekat dari petunjuk yang ada pada label (4).

Protein yang didapatkan dari susu botol lebih tinggi dari ASI. Susu sapi mengandung protein tiga kali lipat lebih banyak dari ASI. Kelebihan protein yang dikonsumsi menyebabkan lebih banyak sel-sel dibentuk didalam badan (hiperplasia) yang melebihi dari seharusnya. Kadar natrium dalam susu sapi juga lebih tinggi tiga kali lebih dari kadar natrium dalam ASI. Hal ini dapat menyebabkan cairan diluar sel dalam badan menjadi lebih tinggi, sehingga osmolality menjadi tinggi. Akibatnya ginjal tidak dapat lebih banyak memekatkan cairan yang dikeluarkan dalam bentuk urine. Bayi menjadi lebih banyak kencing, dan karena banyak kencing bayi akan selalu haus. Bayi yang haus diberikan lagi susu botol, dan begitu seterusnya, sehingga bayi menjadi kebanyakan minum susu botol, yang berarti terlalu banyak mengkonsumsi zat-zat gizi yang berakhir dengan kegemukan (4).

Pada masyakat yang kurang maju, susu botol dapat menyebabkan anak kurang gizi. Tingkat kehidupan yang rendah tidak memungkinkan susu botol terbeli dalam jumlah yang cukup. Susu botol adalah suatu pilihan yang terlalu mahal buat sebagian besar ibu. Oleh karena itu ibu mencampur susu dengan lebih banyak air dari semestinya. Susu botol menjadi sangat encer. Karena terlalu encer, bayi tidak cukup banyak mendapat zat-zat gizi yang dibutuhkannya, lama kelamaan bayi menjadi kurus akhirnya menderita kurang gizi. Selain itu bakteri sangat mudah tumbuh di dalam susu botol terlebih pada keadaan hangathangat kuku dan pada botol yang kotor. Bila ada sisa-sisa susu di dalam botol, bakteri tumbuh disitu. Jika botol itu diisi lagi dengan susu, bakteri berkembang-biak disana. Dan apabila bayi diberikan susu seperti ini, bayi akan terkena infeksi atau diare yang akhirnya dapat berakibat fatal (5).

Pengalaman di Klinik Gizi di Bogor mendapatkan bahwa anak-anak yang menderita Gizi Buruk pada umumnya mempunyai latar belakang: (i) ayah dan ibu pindah kekota, bayilanak diasuh oleh neneknya; (ii) ayah dan ibu bercerai, menyebabkan ibu bekerja mencari nafkah, dan bayi/anak diasuh oleh kakaknya; (iii) ASI tidak keluar karena ibu hamil lagi; dan (iv) bayilanak tidak mau menetek karena diare. Berdasarkan hal-hal hal tersebut bayi tidak diberi ASI melainkan susu botol sebagai penggantinya. Praktek pemberian susu botol dan kondisi lingkungan seperti digambarkan 
di atas menyebabkan banyak anak menderita Gizi Buruk (6).

\section{UPAYA MENINGKATKAN TUMBUH KEMBANG ANAK}

Upaya untuk meningkatkatkan gizi anak, merupakan upaya yang mencakup peningkatan tumbuh dan kembang anak. Berdasarkan alasan-alasan dikemukakan di atas maka upaya tersebut dapat dilakukan melalui: (i) perbaikan praktek ibu dalam memberi makan bayi, (ii) peningkatan praktek ibu dalam menjaga kebersihan diri dan lingkungan serta higiena makanan; dan (iii) peningkatan pola asuh anak (7). Di bawah ini akan diuraikan upaya-upaya tersebut satu persatu.

\section{PERBAIKAN PRAKTEK MEMBERI MAKAN BAYI}

\section{Makanan Bayi Umur 0 - 6 Bulan.}

Dari lahir sampai umur 6 bulan, bayi hanya membutuhkan air susu ibu (ASI), karena semua zat-zat gizi yang dibutuhkannya dapat dipenuhin dari ASI. ASI sebaiknya diberikan tidak dibatasi melainkan dlayani settiap kali ia memintanya, setiap kali ia mau tidur, dan setiap kali ia akan tidur, atau disebut on demand (8).

Pertumbuhan bayi terjadi sangat cepat, sehingga pada usia 6 bulan berat badannya akan dua kali lebih besar dari berat badan lahir. Bertambah besar bayi bertambah besar kebutuhannya akan zat-zat gizi, sehingga bayi yang bertambah umurnya bertambah kuat menyusunya. Gerakan mulut dan lidah bayi merangsang produksi air susu ibu. Makin kuat gerakan tersebut makin bertambah banyak produksi ASI. Dari umur 0 sampai 6 bulan, produksi ASI dapat memenuhi semua kebutuhan bayi (8).

\section{Makanan Bayi Usia 6 - 9 bulan.}

Pada usia 6 bulan, bayi sudah dapat diperkenalkan buah-buahan dan sayursayuran serta tepung-tepungan. Tepung beras atau gandum dan tepung kacangkacangan mudah dicerna oleh bayi.
Makanan bayi dimulai dengan memberi bubur susu yang terdiri dari campuran tepung beras atau tepung lainnya, susu dan air yang sudah mendidih yang dimasak sesuai dengan kebiasaan. Pada hari pertama dapat diberikan $1 / 2$ sampai 1 sendok, dan secara perlahan-lahan naik menjadi 1 atau 2 sendok makan, dan seterusnya. Juga pada bayi mulai dapat diberikan pisang yang dikerok dan jus buah-buahan (sari buah) dengan pendekatan yang sama, yaitu dimulai dengan jumlah sedikit lalu berngsurangsur bertambah banyak. Pengenalan makanan baru ini diteruskan beberapa hari sebelum ia dikenalkan dengan makanan baru lainnya. Cara ini memberi kesempatan kepada bayi untuk menyenangi makanan tersebut (9).

Harus selalu diingat bahwa cita rasa bayi adalah blank (tidak punya rasa), karena itu bayi tidak membutuhkan penambahan gula atau garam. Mungkin menurut ibu rasa makanan bayi tidak enak karena tidak ada rasa, tetapi sesungguhnya cukup enak buat bayi, dan bayi menyenanginya. Cita rasa bayi dibentuk oleh ibunya, yaitu apabila ibu memberinya makan makanan yang rasanya manis, dikemudian hari anak terbiasa dengan makanan manis, atau ibu terbiasa memberinya makanan asin dikemudian hari dia hanya senang makanan yang rasanya asin dan menolak makanan yang rasanya berbeda. Tetapi apabila ibu memberinya makanan yang tidak manis dan tidak asin, dikemudian hari anak senang makanan seperti rasa makanan yang diberikan sewaktu ia bayi, dan yang terakhir ini adalah piihan yang terbaik. Akan lebih baik lagi bila ia diperkenalkan juga bermacam rasa sayur dan buah, dikemudian hari ia akan juga senang makan sayur dan buah.

Pada usia 6 - 9 bulan, bayi sesungguhnya sedang belajar makan dan belajar menyenangi bermacam-macam bahan makanan. Apbila ibu memberikan bermacam-macam bahan makanan, maka ia akan senang bermacam-macam makanan, dan ini menjadi kebiasaan makan dikemudian hari dimana ia akan senang segala macam makanan yang pernah diperkenalkan kepadanya sewaktu masih 
bayi. Dengan makan bermacam-macam bahan makanan, maka kebutuhan akan banyak macam zat gizi juga terpenuhi, dan merupakan jaminan terhadap pertumbuhan dan kesehatan badan yang optimal serta perkembangan kecerdasan yang didambakan oleh ibu dan keluarga.

Bayi berumur di atas 7 bulan sudah dapat mengunyah makanan lembek, seperti serealia, daging yang dimasak empuk, hati, ikan, tempe, tahu, telor, sayur-sayuran dan buah-buahan, dan lain-lain. Makanan ini membuat bayi dapat melatih gigi dan gusi. Hindarkan memberi makanan seperti kacang tanah, sayuran mentah atau lalab, Iolies, gula-gula, coklat, dan lain-lain. Pada usia ini bayi juga dapat memberi respon apabila namanya dipanggil, meniru apa yang dikerjakan pengasuhnya, duduk tanpa dibantu, belajar merangkak, dan berupaya minum air didalam gelas dengan dibantu (9) (10).

\section{Makanan Bayi Usia 9 -12 Bulan}

Pada umur 9-12 bulan, bayi dapat duduk di atas kursi sewaktu diberi makan, dan dapat bergabung dengan keluarga pada waktu makan. la dapat memegang sendok dan berusaha makan sendiri. la dapat merangkak dan senang melambai-lambaikan tangan, bertepuk tangan, serta bicara. la dekat dengan ibunya lebih dari biasanya. Pada umur 12 bulan, berat badannya dapat mencapai 3 kali lebih besar dari berat lahir.

Walaupun bayi pada umur itu makan bermacam-macam makanan, tetapi jangan diberikan makanan yang bersaus banyak, pedas, makan yang digoreng atau yang ditambah garam atau gula. Ibu harus ingat bahwa bayi sedang belajar makan yang akan berkembang menjadi kebiasaan makan pada usia dewasanya.

Pada usia ini, bayi mulai senang beragam makanan dalam volume yang tidak besar. la menghendaki makanan yang bermacam-macam terutama berasal dari bahan pangan setempat, namun ASI terus diberikan. Pada umur 12 bulan, bayi dapat minum susu penuh (whole cream milk) dalam gelas, sebagai ganti susu bayi komersial. Ibu tetap melanjutkan memberi
ASI sampai pada usia dimana ia siap untuk disapih (9)(10).

\section{Makanan Anak Usia 12 - 24 Bulan}

Pada usia 12 - 24 bulan, anak lebih tertarik untuk bermain dari pada makan. Anak mulai dapat berjalan, mulai berbicara, dapat makan dan minum tanpa berceceran dan dapat mulai dilatih kebiasaan ke toilet.

Pada hari ulang tahun pertama, anak barangkali sudah mempunyai gigi $6-8$ buah. Pada usia 12 - 15 bulan, gigi geraham pertama tumbuh, diikuti gigi geraham ke dua pada usia 24 bulan. Pada masa pertumbuhan gigi yang cepat ini, anak kadang-kadang merasa kurang nyaman sehingga dapat terganggu kebiasaan makan dan kebiasaan tidur. Untuk menjaga kesehatan gigi, hendaknya jangan dibiasakan memberi makan makanan bergula, serta mulai dibiasakan menggosok gigi. Hendaklah selalu diusahakan jangan sampai anak tertidur pada saat sedang minum susu botol, karena dapat menyebabkan kerusakan gigi (9)(10).

Pada usia 12 - 24 bulan nafsu makan anak sering berubah-ubah. Kadang-kadang ia senang makan, kadang-kadang ia menolak makan. Ibu harus sabar dengan nafsu makan anak yang berubah-ubah ini. Sistem pencernaan anak mulai dapat mencerna makanan padat, namun ASI tetap diberikan. Serealia, sayur-sayuran dan buahbuahan yang berserat seperti yang dimakan oleh orang dewasa dapat diberikan kepada anak. Pada usia ini anak sudah mulai senang makan makanan kecil atau jajanan. Anak membutuhkan makanan dalam jumlah kecil sepanjang hari. Makanan kecil yang bergizi sama pentingna dengan makanan utama.

Anak membutuhkan minum lebih banyak. Air putih yang direbus tanpa diberi gula adalah baik untuk mencegah kehausan. Berikan contoh bagaimana anak minum sendiri dengan tertib, sehingga bisa ditirunya. Pada usia ini anak senang meniru kebiasaan ibunya. 


\section{PERBAIKAN PERILAKU BERSIH}

Pada umumnya, orang hanya mengetahui bahwa bahwa Kurang Gizi atau Gizi Buruk disebabkan oleh kekurangan makan. Sebenarnya masalahnya sangat kompleks. Faktor-faktor utama yang juga berperanan adalah faktor kebersihan seperti tersedianya air bersih, higiena perorangan dan kebersihan lingkungan, serta pola asuh atau pengasuhan anak. Apabila kita lalai terhadap ketiga faktor tersebut yaitu makanan, kebersihan diri dan lingkungan, serta pengasuhan anak akan menyebabkan masukan zat gizi berkurang dan mudah timbul infeksi sehingga anak akhirnya menderita Kurang Gizi (11).

Infeksi terutama diare, dikenal sebagai penyebab utama rendahnya nafsu makan pada anak dan kurang berfungsinya proses pencernaan zat-zat gizi dan metabolisme. Infeksi disebabkan karena rendahnya kebersihan rumah, kebersihan lingkungan, rendahnya akses atau tidak tersedianya air bersih, lingkungan kumuh dan penuh sesak, dan sebagainya. Prevalensi diare sangat tinggi di daerah yang kondisinya sedemikian (11).

Baru-baru ini proyek "mencuci tangan" dilaksanakan di beberapa negara sedang berkembang. Dengan membiasakan mencuci tangan saja sebanyak $42 \%$ prevalensi diare dapat diturunkan. Proyek yang sama juga sedang berjalan di Sumatera Utara. Sejalan dengan ini, kami menghibau agar berprilaku mencuci tangan dengan sabun pada setiap kali melakukan sesuatu, seperti setiap kali mau makan, setiap kali mau meneteki anak, setiap kali mau memberi makan anak, setiap kali habis buang air, dan setiap kesempatan lainnya. Haruslah dipraktekan dalam kehidupan kita sehari-hari selalu "mencuci tangan" dengan bersih.

\section{PERBAIKAN POLA ASUH ANAK}

Kebutuhan Anak yang Universal
Pengasuhan anak didefinisikan sebagai perilaku yang dipraktekkan oleh pengasuh (ibu, bapak, nenek, atau orang lain) dalam memberikan makanan, pemeliharaan kesehatan, memberikan stimuli serta dukungan emosional yang dibutuhkan anak untuk tumbuh kembang. Juga termasuk didalamnya tentang kasih sayang dan tanggung jawab orangtua (12).

Pengasuhan yang baik sangat penting untuk dapat menjamin tumbuh kembang anak yang optimal. Misalnya pada keluarga miskin, dimana ketersediaan pangan di rumah tangga belum tentu mencukupi, namun ibu yang tahu bagaimana mengasuh anaknya, dapat memanfaatkan sumbersumber yang terbatas untuk dapat menjamin tumbuh kembang anak yang optimal. Sebagai contoh, menysui anak adalah praktek memberikan makanan, kesehatan, dan pengasuhan yang terjadi bersamaan. Perilaku ibu seperti cara memelihara kebersihan rumah, higiena makanan, kebersihan perorangan, dan praktek psikososial adalah faktor-faktor penting yang berpengaruh terhadap proses tumbuhkembang anak. Demikian pula faktor lingkungan seperti ketersediaan air bersih di dalam rumah, bahan pangan yang tersedia untuk makanan sehari-hari, dan pengetahuan ibu atau pengasuh lainnya. Latar belakang pendidikan ibu, serta keadaan kesehatan fisik dan mental, dan kemampuan ibu mempraktekkan pengetahuan yang dipunyainya dalam kehidupan sehari-hari, serta dukungan emosional anggota keluarga lainnya, tetangga dan masyarakat, semuanya berakumulasi dalam membentuk kualitas tumbuh kembang anak (11)(12).

Praktek pengasuhan dan sumbersumbernya berbeda antar daerah karena perbedaan budaya, dan bahkan antar keluarga pada daerah atau budaya yang sama. Namun kebutuhan anak terhadap makanan, kesehatan, perlindungan dan kasih sayang adalah universal. Perubahan di dalam keluarga dapat terjadi karena urbanisasi, peningkatan peranan wanita dalam ekonomi keluarga, dan pendidikan yang lebih tinggi, yang kesemuanya 
berakibat meningkat kebutuhan akan perubahan dan adaptasi dalam praktek pegasuhan anak.

\section{Respon terhadap Isyarat dan Perkem- bangan Fisik}

Salah satu respon adalah bagaimana ibu atau pengasuh membaca atau memahami tanda-tanda dan kebutuhan anak, menterjemahkannya secara hati-hati, dan meresponnya secara cepat, benar dan konsisten. Salah satu contoh anak menangis karena sesuatu hal maka ibu tidak ada waktu meresponnya atau salah menginterpretasikan sebab-sebab anak menangis, maka ibu akan kehilangan kesempatan memberi makan anak jika anak menangis karena lapar.

Kemampuan dan sensitivitas orangtua menginterpretasikan isyarat-isyarat anak, memudahkan tumbuh-kembang anak mencapai derajat optimal. Sensitivitas adalah kemampuan menerima dan menginterpretasikan isyarat-isyarat atau sinyal-sinyal dari anak, dan meresponnya secara benar. Oleh karena itu orangtua dituntut mampu memberi bimbingan kepada anaknya pada daerah dimana anak mampu melakukannya (12).

Agar supaya orangtua mampu melaksanakan fungsinya dengan baik, maka perlu orangtua memahami tingkat perkembangan anak, menilai pertumbuhan atau perkembangan anaknya, dan mempunyai motivasi yang kuat untuk memajukan tumbuh-kembang anak.

\section{Makanan Lokal Meningkatkan Gizi dan Kecerdasan Anak}

Makanan suplemen yang diberikan berupa makanan kecil dibuat dari bahan makanan lokal dan dimasak menurut resepresep setempat, terdiri dari beras, tepung beras, tepung gandum, roti, singkong, ubi jalar, kentang, santan, gula pasir, gula merah, dan minyak goreng, diberikan kepada 334 anak umur $6-30$ bulan. Hasil penelitian ini menyimpulkan bahwa suplemen makanan mempengaruhi pertumbuhan dan domain perkembangan secara simultan (12). Delapan tahun kemudian kami kembali, dan mendapatkan 231 anak dari 334 anak yang dahulu ikut-serta dalam penelitian. Hasil pengukuran mendemonstrasikan bahwa suplemen makanan selama tiga bulan pada waktu bayi berumur kurang dari 18 bulan membawa keuntungan yang nyata terhadap kecerdasan anak sampai 8 tahun kemudian (13).

Pemberian makanan yang terbuat dari bahan pangan lokal, dan dengan resep masakan setempat yang diberikan kepada bayi dan anak usia muda meningkatkan kecerdasan anak, serta mempunyai efek panjang sampai ia duduk dibangku sekolah (13)(14).

\section{KESIMPULAN}

1. Kurang gizi adalah akibat dari pemberian makanan yang tidak cukup memenuhi gizi dalam hal kualitas maupun kuantitas berkombinasi dengan seringnya anak menderita sakit terutama diare.

2. Tumbuh kembang optimal adalah hasil dari makanan bergizi dan cara bagaimana ibu memberikannya. Bayi yang terlalu gemuk atau terlalu kurus adalah akibat kesalahan memberi makan. Makanan yang diberikan oleh ibu kepada bayinya amat menentukan kualitas hidup anak bersangkutan pada masa sekarang dan masa yang akan datang.

3. Ada dua aspek penting tentang gizi bayi: (1) bayi membutuhkan makanan yang memenuhi tumbuh kembang dan kesehatan; dan (2) bayi belajar bagaimana seharusnya ia makan. Makanan yang biasa ia dapatkan sekarang tertanam akan menjadi perilaku makan di kemudian hari.

4. Pengasuhan anak dalam hal perilaku yang dipraktekkan oleh pengasuh (ibu, bapak, nenek, atau orang lain) dalam memberikan makanan, pemeliharaan kesehatan, memberikan stimuli serta dukungan emosional dan kasih sayang memberikan kontribusi yang nyata 
terhadap perkembangan intelektual anak.

5. Bahan pangan lokal dengan resep makanan setempat yang diberikan kepada bayi dan anak usia muda meningkatkan kecerdasan anak; dan tingkat kecerdasan yang lebih tinggi ini dipertahankan sampai ia besar.

6. Keadaan sehat dan kecerdasan pada masa yang akan datang tergantung pada bagaimana ibu memberi makan anak sekarang.

\section{RUJUKAN}

1. Martorell R. The nature of child malnutrition and its long-term implication. Food and Nutr Bull1999; 20: 288-292.

2. WHO. Management of Severe Malnutrition: A Manual for Physicians and other Senior Health Workers. Geneva, 1999.

3. Min.of Health R.I. Indonesia Health Profile 2003. Jakarta 2005.

4. Naistmith DJ. Maternal and infantile obesity - a common etiology? Van den Berghs \& Jurgens 1973 Nutrition Award, Queens Elizabeth College, Univ of London.

5. Brown KH, Dewey KG, Allen LH. Complementary feeding of young children in developing countries: a review of current scientific knowledge. 1998. WHO/NUT/98.1.1 Geneva: World Health Organization, 1998.

6. Husaini YK, Sulaeman Z, Basuki SM, Karyadi D. Outpatient rehabilitation of severe energy malnutrition (PEM). Food and Nutr Bull1984; 8: 55-59.

7. Ruel MT. Urbanization in Latin America: Constraints and opportunities for child feeding and care. Food and Nutr Bull 2000; 21: 12-23.

8. Anonymous. Breastfeeding, birth spacing and nutrition. SCN News, Mid1997; 7-14.

9. Brown KH and Lutter CK. Potential role of complementary foods in the improvement of early childhood nutrition in Latin America. Food and Nutr Bull 2000; 21: 5-11.

10. Dewey KG, Cohen RJ, Browwn KH, Rivera LL. Age of introduction of complementary foods and growth of term and breastfed infants. Am J Clin Nutr 1999; 69:676-86.

11. Hoet JJ. Poor nutrition and chronic diseases. SCN News, July 1997; 60-62.

12. Gillespie S. An overview: nutrition and poverty. Proceeding: ACC/SCN 24th Session Symposium. Kathmandu, March 1997; 1-18.

13. Husaini MA, Karyadi L, husaini YK, Sandjaja, Karyadi D, Pollitt E. Developmental effect of short-term supplementary feeding in nutritionallyat-risk Indonesian infants. Am J Clin Nutr 1991; 54: 799-804.

14. Pollitt E.; Watkin WE, Husaini MA Three-month nutritional supplementation in Indonesian infants and toddlers benefit memory function 8 y later. Am J Clin Nutr 1997; 66: $1357-$ 1363. 